\title{
3
}

\section{Resisting the ascendancy of an emboldened colonialism}

\author{
Cathryn Eatock
}

We continue to ensure that our land, law, language and culture lives on and continues to be vibrant and long-lasting. We do this by getting back our country, looking after our country and securing our future. (Kimberley Land Council 2016: 3)

Indigenous policy in Australia has undergone a shift over the last two decades, retreating from previous commitments to self-determination, and implementing paternalistic approaches based on an underlying neoliberal ideology that seeks to control and assimilate Aboriginal people to fit within a market model (Altman 2007: 2, Moreton-Robinson 2009: 68, Howard-Wagner 2012: 237). However, the assimilationist intent of these policies and the application of neoliberal approaches to Aboriginal communities ignores the direct causal link between colonialism and Aboriginal poverty and disregards the communal nature of Aboriginal culture. The relationship between neoliberalism and paternalism is explored in a number of chapters within this volume (e.g. Sullivan, Howard-Wagner, Bielefeld, Page). Despite the adoption of the United Nations Declaration on the Rights of Indigenous Peoples (UNDRIP) in 2007, government policies impacting Indigenous peoples in Australia have taken a clearly paternalistic tone, with assimilationist objectives. This chapter considers recent policy changes through the Resilient families, strong communities: A roadmap for regional and remote communities report 
(RFSC report), which sets out the termination of services to smaller remote Aboriginal communities in Western Australia (WA), as a means to close approximately 120 communities and pressure their community members to move to larger regional and hub towns. This chapter highlights how Indigenous policy is being used to disempower and dispossess Aboriginal communities, as a means to break their unique communal connection to land. The chapter contends that the primacy given to neoliberal objectives by both major political parties has required Indigenous peoples to look beyond the hegemony of the nation state in an attempt to draw on the United Nations (UN) mechanisms and seek engagement with the global community. In leveraging emerging international customary law and associated norms, Aboriginal people strive to pressure the Australian Government to implement its international commitments, to recognise Indigenous rights and to negotiate just outcomes with Australia's Indigenous peoples.

\section{Contemporary colonial dispossession}

Our land is viewed as a common legacy to be handed down to our children and grandchildren-Walter Shaw. (Aboriginal Peak Organisations of the Northern Territory 2015: 32)

The announced closure of up to 150 remote Aboriginal communities by the WA Government, in November 2014, sent fear through the 274 Aboriginal communities in WA. This announcement followed the federal government's decision to transfer responsibility for these communities to the state government. The WA Premier, Colin Barnett, acknowledged 'it will cause great distress to Aboriginal people who will move, it will cause issues in regional towns as Aboriginal people move into them' (Kagi 2014). However, the government justified its decision by claiming these communities were financially unviable and harboured social dysfunction, neglect and child abuse.

The then prime minister, Tony Abbott, further inflamed concerns among remote communities when, in March 2015, he stated 'what we can't do is endlessly subsidise lifestyle choices if those lifestyle choices are not conducive to the kind of full participation in Australian society that everyone should have' (Medhora 2015). This statement highlighted a profound ignorance of the complex cultural connection to country and ties to ancestors, lore and custodial obligations that define remote 
communities. It also put forward the ideological basis of a policy approach where an individual's worth was premised against their market value as potential employees, and the poverty of Aboriginal communities was seen as an individual and community failure. It also ignored the fact that the wealth of WA's mining and petroleum exports, totalling AU $\$ 98.0$ billion in 2012-13 (WA Department of Treasury 2014), had been drawn from the ancestral lands from which Aboriginal people had previously been dispossessed and remained uncompensated. Significantly, it also highlighted an abrogation of the rights of indigenous peoples asserted in the 2007 UNDRIP, which the Australian Government had endorsed in 2009 .

The announcement reflected that government policies targeting Aboriginal communities had enacted a neoliberal form of 'managerialism' that disempowers and dispossesses Aboriginal communities, to progress an openly assimilationist intent to break communal connections to land. Neoliberalism, which has prevailed over Western political economies for the last 30 years, refers to a laissez faire form of capitalism that ascribes dominance to the power of market forces (Monbiot 2016). Von Hayek defines neoliberalism as deregulation and fostering of markets, deregulation of labour, reduction of social welfare, privatisation of services, reduction of state regulation and rejection of collective unionism (Von Hayek 1944, cited in Klikauer 2015: 1107). According to Klikauer, 'managerialism' is closely linked with market-oriented reforms, including economic rationalism and neoliberalism, that assert corporate interests as the universal interest of humanity, under the banner of globalisation (Klikauer 2015: 1107, 1113). Neoliberals argue that the welfare state undermines individual responsibility, where welfare recipients become dependent, and see the role of the state as disciplining welfare recipients through punitive measures to discourage long-term welfare dependency (Mendes 2009: 105). When applied to Aboriginal communities, it both ignores that Aboriginal poverty is a direct result of colonialism and that Aboriginal culture is based on a communal rather than an individualistic framework.

These policy approaches reflect a neoliberal conception of modernisation, which seeks to impose assimilationist measures that require viewing Aboriginal communities as 'failed citizens' who need to be compelled to assimilate (Altman 2007: 2). Neoliberal managerialist approaches view cultural difference negatively, as a social determinant that limits opportunity, where, according to Sanders, 'certain people are not adequate 
judges of their own best interests and must be guided by others, such as government agents' (2014: 1). The imposition of individual land title over communal title and the removal of communities from ancestral lands are promoted as the means to achieve this assimilation.

Following the announced closure of remote communities, the WA Government developed the RFSC report, released in July 2016, noting Aboriginal people are more dependent on welfare than other West Australians, particularly in regional and remote communities, stating '[c] hange will take time and some of it will be hard.' (Government of Western Australia 2016: 3). While the report claims it will consult with Aboriginal communities, the central decisions are laid out, preventing any real input into decision-making. Rather, the RFSC report confirms the WA Government will cut services, including essential fuel subsidies, to remote communities it claimed were not economically viable, even though the fuel is used to power generators that provide critical water pumps and electricity to communities (Government of Western Australia 2016: 16).

The report reflects a policy intent to replace Indigenous social norms with those more aligned with a Western market-based approach. The RFSC report takes a deficit approach that holds Aboriginal communities responsible for the deprivation in their communities, with perceptions of dysfunction used to justify, in part, the closure of remote communities. However, independent reports confirm Aboriginal people have significantly better health and wellbeing outcomes in remote communities compared to Aboriginal people living in larger townships (Amnesty 2011:3). Improved health outcomes are attributed to increased cultural practice, social and family support, greater physical activity and a healthier diet reliant on more traditional bush foods (Mooney 2009: 17). Remote communities also have fewer social problems and less domestic violence and substance abuse, while providing respite and rehabilitation from substance abuse for Aboriginal youth from towns and cities. These outcomes contrast to those in townships, where people experience higher rates of social dysfunction and disadvantage (Amnesty 2011: 13).

While the RFSC report highlights the low 20 per cent employment rate in remote Aboriginal communities as a justification to close communities, employment levels of only 43 per cent in regional towns (Government of Western Australia 2016: 6) fail to promise employment opportunities. It also disregards the fact that the largest employer in remote communities was the Community Development Employment Projects (CDEP) 
program, which was abolished in previous reforms. CDEP had provided employment through the topping up welfare payments; though it only provided a minimal wage, it gave community control over the type of services supported, such as childcare, teacher support, community maintenance and elder care, over the 30 years it operated. In the West Kimberley region alone, seven CDEP providers employed 1,600 people, where the CDEP program was considered the lifeblood of communities (CDEP Submission 2011: 3).

Although the RFSC report alleges twice as much spending on Aboriginal people in remote and regional areas compared to non-Aboriginal urban dwellers, citing this as a further justification for the closing of communities, these statistics actually reflect decades of underspending, with communities now chronically overcrowded and many with faulty water and sewage services (Australian Indigenous Health Infonet 2008: 5-6). However, the RFSC report confirms no further funding will be allocated to housing maintenance or additional building in smaller communities, with funding for schools and services to cease. The RFSC instead advocates funding be limited to 10 larger communities that are close to a major source of employment and educational opportunities. The report states new housing will 'preference transitional housing over current models of public and community housing' (Government of Western Australia 2016: 34). To qualify for 'transitional housing', tenants will be required to have one adult in employment and an 85 per cent school attendance rate for children. Transitional housing, the report suggests, is designed to transition tenants to private rental or home ownership. However, while this housing will be released onto the private market, there is no guarantee that the tenants will become owners. Indeed, the high cost of building in remote regions and the low wages of unskilled workers indicates a likely low uptake. In addition, the report commits to change the land tenure of existing housing to remove current communal title (Government of Western Australia 2016: 20).

The RFSC report also argues the distance to markets is an impediment to 'self-determination'. This assertion misrepresents the term's actual meaning, which defines Indigenous decision-making rather than being a reference to employability. In basing policy objectives on a neoliberal market framework, the RFSC report rejects the notion that Aboriginal values and community aspirations may vary from market-based conceptions. Howard-Wagner argues that neoliberal market-driven policies are used to enforce a paternalistic approach, regulating communities and 
breaking up communal land ownership, which is used to reconstitute a 'neo-settler colonialism' that restructures land tenure away from community ownership to individual housing tenures (Howard-Wagner 2012: 224).

\section{Part of a broader ideological strategy}

This home ownership really upsets me ... We own our land and our home is on the land. Our land is where we have ceremony and share culture. We do own our home. Our home is our land. Home is where our grandmothers and grandfathers have been hunting and living. Home is where we belong to, it's our land. The land is our home-Phillip Wilyuka. (Aboriginal Peak Organisations of the Northern Territory 2015: 21)

The RFSC report implements recommendations of the Creating parity report by Andrew Forrest (the Forrest Review), a WA mining magnate commissioned by the federal government to review Aboriginal employment and training in 2014. The Forrest Review criticises the provision of social housing in remote communities, considering it a disincentive to out-of-region employment, and proposes limiting 'continuing eligibility for public housing for those who take up and retain work for up to 30 months while they transition to the private rental market or home ownership' (Forrest 2014: 46). The review also advocated for the removal of CDEP: though it confirmed people were better off on CDEP, it called for 'equality' with non-Aboriginal people and 'real jobs' in Aboriginal communities (Klein 2014: 4). However, the Forrest Review's flawed assumptions failed to acknowledge the differing cultural values of remote communities that prioritise custodial responsibilities over financial incentives (Klein 2014: 3). The report also argues for the imposition of 'Income Management', a costly and punitive welfare reform that limits access to cash payments (a topic addressed by Bielefeld in this volume, Chapter 8).

Imposing private ownership of lands as a means to overcome poverty was promoted by Hernando De Soto, in the Mystery of capital, and embraced by neoliberal market advocates (De Soto 2003). Helen Hughes and Jenness Warin draw on De Soto to argue communal ownership impedes the productive use of land, employment creation, and economic development worldwide' (Hughes \& Warin 2005: 4), where the poor are marginalised from the global economy because of their incapacity to attract loans and 
by the potential sale of property. However, Peter van Dijk, South African Micro Finance Council, warns 'if it is simply a swapping of debt, there is no added value' (cited in Tom 2005: 24). Transferring De Soto's theory to remote Aboriginal communities poses additional challenges. At a forum on 'Access to Finance on Aboriginal Lands', bankers raised concerns over low demand, high costs of construction and high-risk profiles of lenders in remote communities, noting resale prices will likely be lower than purchase prices (Tom 2005: 27). They also noted that in communities where mines may contribute to demand, the greater purchasing power may have 'significant implications for the make-up of a remote Aboriginal community’ (Tom 2005: 27).

The Australian Government's Our north, our future: White paper on developing northern Australia (Australian Government 2015) proposes means of creating economic opportunities through the development of Aboriginal lands and the establishment of simpler land arrangements to support investment, highlighting untapped opportunities for home ownership and leasing arrangements. However, the Australian Human Rights Commission has raised concerns that it 'might have implications for breaking up Aboriginal and Torres Strait Islander communities and diminishing their land ownership' (Australian Human Rights Commission 2015: 76). The White Paper also recommends amendments to the Aboriginal and Torres Strait Islander Heritage Protection Act 1984 (Cwlth) to simplify cultural heritage regulation, which it suggests is a key barrier to economic development in the north.

David Pick et al., in their review of the impact of neoliberalism on development in WA's Pilbara region, the location of many of the targeted remote Aboriginal communities, suggest neoliberalism has resulted in the weakening of regulation and led to a 'leakage of wealth' from the region (Pick et al. 2008: 518). Pick et al. also confirm development pressures are particularly intense in the Pilbara region, with virtually all of Australia's iron ore, gas and oil extracted from the region (Pick et al. 2008: 519). They argue that neoliberal policies, prioritising economic factors over social needs, had become the norm, where 'the dispossession of Indigenous peoples has led to a number of issues that are proving difficult to resolve' (Pick et al. 2008: 524-5). Significantly, Pick et al. suggest the dependence on mining may prove detrimental in the long term, with no alternatives to the resource industry being developed (Pick et al. 2008: 521). 
Western imperialism drew on religious theology and the 'Doctrine of Discovery' to promulgate the superiority of Western civilisation and modernisation as a justification for the exploitation of indigenous lands and decimation of indigenous cultures. Where Aboriginal communities vary from this perception of civility, they are conceived as dysfunctional and are pathologised as a means to subjugate Aboriginal people (Moreton-Robinson 2009: 63, Alfred 2015: 5). The problematising of indigenous peoples deflects the historical and structural causes of indigenous deprivation, as a means for the government to lay responsibility for their impoverishment on individuals, while the ramifications of dispossession and decades of neglect are ignored (Alfred 2015: 5). Aileen Moreton-Robinson argues the denial of the impact of colonisation in producing economic dependency serves to make the ongoing race war against Indigenous peoples invisible (Moreton-Robinson 2009: 70).

The globalisation of neoliberalism has re-energised these colonial assaults in an attempt to erase Indigenous claims, remove connection to place and separate entitlement, completing earlier processes of dispossession (Alfred \& Corntassel 2005: 603, Howard-Wagner \& Kelly 2011: 121). It is neoliberalism's market-dominated approach that privileges individual rights over communal rights, which, according to Moreton-Robinson, enables 'the impoverished conditions under which Indigenous people live to be rationalised as a product of dysfunctional cultural traditions and individual bad behaviour' (Moreton-Robinson 2009: 68).

Neoliberals assert that the welfare state undermines individual responsibility, where welfare recipients, like addicts, become dependent on welfare. This has led to punitive measures to discourage welfare dependency and assert a work ethic and self-reliance (Mendes 2009: 105). In Aboriginal communities, regulatory and punitive policies are pursued, seeking to assert behavioural change to assimilate these communities into a market-focused framework (Howard-Wagner 2007, HowardWagner \& Kelly 2011, Bielefeld 2014/2015: 106-7). These policies seek to impose a 'normalisation' on Aboriginal people, through assimilation policies aimed at reproducing lifestyles of the broader Australian community (Howard-Wagner 2007: 246, Sullivan 2011: 3). Will Sanders suggests Indigenous policy approaches have returned to an emphasis on guardianship, particularly in relation to remote and discrete Aboriginal communities that were previously given a degree of autonomy more focused on self-determination and the recognition of land rights as decolonisation strategies (Sanders 2014: 9). 
Yet, Aboriginal people living in remote communities assert their right to maintain their cultural values, protect sacred sites and establish alternative economic development initiatives that align with their custodial obligations. Jon Altman argues that remote Aboriginal communities do not fit within a narrow neoliberal market framework. Remote communities' reliance on bush foods, and income derived from environmental management practices and cultural expressions, all contribute to what Altman terms the local 'hybrid economy' that respects traditional lifestyles and values customary decision-making processes (Altman 2011: 4-5). This 'contested notion of economic development' contrasts with policy objectives focused on employment, business and home ownership (Altman 2011: 3). The Indigenous estate, according to Altman, covers 20 per cent of Australia and holds some of the most biodiverse and intact lands in Australia, with untapped potential for carbon emission sequestration and environmental management strategies. Altman challenges government approaches that correlate community development with economic development as a process of modernisation that assesses Aboriginal communities from a deficit perspective (Altman 2011: 4).

\section{Seeking a just footing}

We Aboriginal people have the solutions. We just need [the federal government] to invest in that. I'm travelling around the country talking about treaty, about recognition of our sovereignty. We were here before the British and we need it to be recognized that our law and our system of government is valid-Yingiya Guyula. (Clarke 2016: 2)

With both major political parties asserting a neoliberal agenda, often at the expense of Indigenous rights, Aboriginal people strive to leverage international mechanisms that recognise Indigenous rights to self-determination and 'free, prior and informed consent' (FPIC) as fundamental emerging norms in international law. Although the Universal Declaration on Human Rights and its core treaties initially did not recognise the particular circumstances of indigenous people, James Anaya argues the adoption of the UNDRIP ${ }^{1}$ now constitutes international customary law (Anaya 2009: 80). The right to selfdetermination, Article 3 of the Declaration, is, according to Anaya,

1 For the full text of the UNDRIP, see www.un.org/development/desa/indigenouspeoples/ declaration-on-the-rights-of-indigenous-peoples.html. 
'a foundational right, without which Indigenous Peoples' other human rights, both collective and individual, cannot be fully enjoyed' (Anaya 2010: 15). 'Self-determination' as applied in the Declaration is a process of decolonisation that does not necessitate succession, but rather provides a strategy to assert indigenous rights against state and corporate economic and political interests. For the remote communities in WA, Article 10 specifically states, 'Indigenous peoples shall not be forcibly removed from their lands or territories'. In addition, while WA Aboriginal communities' use of water pumps is threatened by the cessation of fuel subsidies for generators, the UN General Assembly has explicitly recognised the right to water as essential to the realisation of all human rights (United Nations General Assembly 2010).

Though Article 46 of the Declaration was a concession that responded to state concerns that their sovereignty was not contested, the Declaration does confer obligations on colonial states to recognise the pre-existing rights of indigenous peoples. Indigenous people continue to assert that the legitimacy of states remains under question where substantial efforts are not undertaken to address those rights recognised in the Declaration as agreed minimal standards, as a central component of instigating decolonisation processes. In the face of increasing global pressures on indigenous peoples, as neoliberal market forces seek to assert economic interests over indigenous peoples' rights, international law is sought to leverage states' compliance with their obligations to recognise indigenous rights to remain on their lands, to self-determination and to 'free, prior and informed consent'.

While the UN reasserts states' sovereign interests, it remains the only institution where state power may be held to account and its impunity curtailed. The Declaration confirms colonial states have an obligation to recognise the pre-existing and inherent rights of indigenous peoples. The challenge now remains how to translate those commitments broadly endorsed in international law into state approaches that respect and facilitate indigenous decision-making on issues that impact upon them. The contention is to move beyond tokenistic acknowledgement of 'aspirational' rights to honouring those international standards of customary law, cementing the communal rights of indigenous peoples to be self-determining peoples with the capacity and resources to express that autonomy, both locally and globally. 
Though the Declaration lacks enforcement mechanisms, it establishes international norms that are broadly accepted as global standards. While states can continue to breach these laws, such breaches may be associated with loss of reputation, international standing and legitimacy (Finnemore \& Sikkink 2014: 903). Though many states continue to breach human rights, state desire to maintain perceptions as 'good global citizens' may be used as potential leverage among states with a history of engagement with the UN, such as Australia. Further, the current Australian Government's appointment to the Human Rights Committee (HRC) 2018-20 term may provide additional leverage when highlighting the disconnect between Australia's global commitment and its national policy approach.

Since the adoption of the Declaration, the HRC and other bodies monitoring the implementation of UN treaties have strengthened their responses in relation to indigenous peoples' right to FPIC before undertaking projects or decisions in relation to indigenous lands (Barelli 2012: 6-8). In addition, the HRC has interpreted Article 27 of the International Covenant on Civil and Political Rights, which protects persons belonging to ethnic minorities to enjoy their culture, noting, 'culture manifests itself in many forms, including a particular way of life associated with the use of land resources, especially in the case of Indigenous peoples' (Barelli 2012: 21).

The Outcome document of the high-level plenary meeting of the General Assembly known as the World Conference on Indigenous Peoples, adopted by the UN General Assembly in September 2014, reaffirmed the Declaration and rights to FPIC, and committed to developing national action plans to implement the Declaration. In addition, at Article 21, the Outcome document also committed to establish nationally 'fair, independent, impartial, open and transparent processes to acknowledge, advance and adjudicate the rights of Indigenous peoples pertaining to lands, territories and resources' (United Nations 2014). Within the UN, it also commits to developing a 'System Wide Action Plan' reviewing the operation of Indigenous mechanisms, treaty bodies and the Universal Periodic Review, and appointed two indigenous experts, alongside two government representatives, to develop indigenous peoples' participation at the UN, including at its General Assembly.

Margaret Keck and Kathryn Sikkink outline the potential to use 'transnational advocacy networks' of civil society to influence more powerful states (Keck \& Sikkink 1998: 1). Keck and Sikkink argue that less 
powerful groups, such as Indigenous peoples, can increase their capacity to influence states through global advocacy and the shifting of international norms, which in turn, through what they term a 'boomerang' effect, can transform practice within state jurisdictions (Keck \& Sikkink 1998: 12). According to Keck and Sikkink, the 'boomerang' effect provides a means to influence states when governments violate or refuse to recognise rights, and domestic recourse is limited or the institutions are ineffective. While the concept of Westphalian Sovereignty is accepted as inalienable in international law, where state sovereignty provides protection from external interference on domestic issues, it is no longer sacrosanct, with developments over recent decades acknowledging responsibility among the international community to monitor human rights within nation states (Pitty \& Smith 2011: 124). Though the Declaration has been termed an aspirational document rather than a legally binding treaty, it is currently 'used in transnational political advocacy as a source of important international norms' (Pitty \& Smith 2011: 126), further asserting its place within emerging international customary law.

Developments in technologies now enable groups to communicate easily and form global alliances over issues that resonate. While incremental policy approaches are less likely to gain traction among a global constituency, issues that highlight stark human rights abuses, such as indigenous dispossession and rights to water, can draw broad global support from divergent groups, as occurred with the North Dakota Pipeline. Though not resolved, it has garnered international support and comment from numerous UN officials (Bearak 2016).

\section{The weight of recrimination}

We want self-determination. We want democracy. We want the power of the people in Arnhem Land and in all Aboriginal communities to be recognised and our rights respected. (Yolngu Nations Assembly 2012)

The attempts to close communities in WA have been perceived as renewed dispossession against remote Aboriginal communities, their rights to selfdetermination and their ancestral lands. The Aboriginal policy climate of recent years has set the state against Aboriginal people, driven by a neoliberal ideological agenda that promotes powerful corporate interests, while implementing a highly paternalistic and managerial approach that strives to eradicate welfare dependency, denigrating Aboriginal people 
in remote communities for their deprivation. These policies of removal instigate a renewed phase of colonialism, through the regulation, enforced assimilation and dispossession of remote Aboriginal communities.

In developing the UN, states have defended their claims to colonised territories and their sovereignty, reflected in a lack of enforceable judicial processes for Indigenous complaints to be fairly adjudicated. While these constraints impinge on the effectiveness of international treaties and mechanisms, limiting potential outcomes for indigenous peoples, the UN remains a key means of defence for indigenous peoples. Without external exposure of the immense power disparities between states and indigenous peoples, where hegemonic powers are driven by neoliberal imperatives, state impunity may threaten the very survival of indigenous peoples as they derogate and deny their unique claims as sovereign nations.

This chapter argues that the abuse of Indigenous rights and apparent disregard for Indigenous rights within an Australian policy context requires collaborative international pressure to address intransigent states that fail to comply with international obligations. While internal reviews within the UN consider processes to increase Indigenous capacity through strengthened mechanisms to address this disparity and encourage state compliance, the force of international law is premised on an engaged global public and international expectations for compliance, which can coordinate political campaigns in response to flagrant breaches. It is through the exposure of domestic abuses to broader scrutiny that the domination of the powerful interests of states and corporations may be curbed.

\section{References}

Aboriginal Peak Organisations of the Northern Territory (2015). Aboriginal remote housing forum, Report prepared by Bisset H, Aboriginal Peak Organisations of the Northern Territory, Darwin.

Alfred T (2015). Cultural strength: Restoring the place of Indigenous knowledge in practice and policy. Australian Aboriginal Studies 2015(1):3-11.

Alfred T \& Corntassel J (2005). Being Indigenous: Resurgences against contemporary colonialism. Government and Opposition 40(4):597-614, doi.org/10.1111/j.1477-7053.2005.00166.x. 
Altman JC (2007). Alleviating poverty in remote Indigenous Australia: The role of the hybrid economy, Topical Issue 10/2007, Centre for Aboriginal Economic Policy Research, The Australian National University, Canberra.

Altman JC (2011). The draft indigenous economic development strategy: A critical response, Topical Issue 3/2011, Centre for Aboriginal Economic Policy Research, The Australian National University, Canberra.

Amnesty (2011). The land holds us: Aboriginal peoples' right to traditional homelands in the Northern Territory, Amnesty International.

Anaya J (2009). International human rights and indigenous peoples, Aspen Publishers.

Anaya J (2010). Report by the Special Rapporteur on the situation of human rights and fundamental freedoms of Indigenous People-Situation of Indigenous Peoples in Australia, Human Rights Council, 4 March.

Australian Government (2011). Stronger futures in the Northern Territory policy statement, November, Canberra.

Australian Government (2015). Our north our future: White paper on developing northern Australia, June, Canberra.

Australian Human Rights Commission (2015). Social justice and native title report 2015, Australian Human Rights Commission, Sydney.

Australian Indigenous Health Infonet (2008). Review of the impact of housing and health-related infrastructure on Indigenous health, Australian Indigenous Health Infonet, Mt Lawler.

Barelli M (2012). Free, prior and informed consent in the aftermath of the UN declaration on the rights of indigenous peoples: Developments and challenges ahead. The International Journal of Human Rights 16(1):1-24, doi. org/10.1080/13642987.2011.597746.

Bearak M (2016). U.N. officials denounce 'inhuman' treatment of native American pipeline protesters. Washington Post, 15 November.

Bielefeld S (2014/2015). Compulsory income management, Indigenous peoples and structural violence-implications for citizenship and autonomy. Australian Indigenous Law Review 18(1):99-118.

CDEP Submission (2011). Reforming CDEP in the West Kimberley, submission to the Employment Services Review Panel.

Clarke A (2016). Indigenous leaders say they're sick of 'being experimented on'. Buzzfeed News Australia, 17 March. 
De Soto H (2003). The mystery of capital: Why capitalism triumphs in the west and fails everywhere else. Basic Books, New York.

Finnemore M \& Sikkink K (2014). International norm dynamics and political change. International Organisation 52(4):887-917, doi.org/10.1162/ 002081898550789.

Forrest A (2014). Forrest review: Creating parity. Report to the Commonwealth of Australia, Canberra.

Government of Western Australia (2016). Resilient families, strong communities: $A$ roadmap for regional and remote communities, Regional Services Reform Unit, Department of Regional Development, Western Australia.

Howard-Wagner D (2007). Restoring social order through tackling 'passive welfare': The statutory intent of the Northern Territory National Emergency Response Act 2007 (Cth) and Social Security and Other Legislation Amendment (Welfare Payment Reform) Act 2007 (Cth). Current Issues in Criminal Justice 19(2):243-51.

Howard-Wagner D (2012). Reclaiming the Northern Territory as settler-colonial space. Arena Journal 37/38:220-40.

Howard-Wagner D \& Kelly B (2011). Containing Aboriginal mobility in the Northern Territory: From 'protectionism' to 'interventionism'. Law Text Culture 15:102-34.

Hughes H \& Warin J (2005). A new deal for Aborigines and Torres Strait Islanders in remote communities. No. 54 Issues Analysis, The Centre for Independent Studies, Sydney.

Kagi J (2014). Plan to close more than 100 remote communities would have severe consequences, says WA Premier. ABC News, 12 November.

Keck M \& Sikkink K (1998). Activists beyond borders: Advocacy networks in international politics, Cornell University Press, London.

Kimberley Land Council (2016). Making rights a reality: The ongoing struggle for land justice in the Kimberley Region, Australia, Briefing Note, Oxfam International, Oxford.

Klein E (2014). Academic perspectives on the Forrest review: Creating parity. Topical Issue 2/2014, Centre for Aboriginal Economic Policy Research, The Australian National University, Canberra.

Klikauer T (2015). What is managerialism? Critical Sociology 41(7-8):1103-119, doi.org/10.1177/0896920513501351. 
Medhora S (2015). Remote communities are 'lifestyle choices', says Tony Abbott. Guardian, 10 March.

Mendes P (2009). Retrenching or renovating the Australian Welfare State: the paradox of the Howard government's neoliberalism. International Journal of Social Welfare 18:102-10, doi.org/10.1111/j.1468-2397.2008.00569.x.

Monbiot G (2016). Neoliberalism—-the ideology at the root of all our problems. Guardian, 15 April:1-7.

Mooney G (2009). Health and homelands: Good value for money? Report for The Institute for Cultural Survival, Aboriginal Medical Services Alliance Northern Territory (AMSANT), MITWATJ Health Aboriginal Corporation.

Moreton-Robinson A (2009). Imagining the good indigenous citizen: Race war and the pathology of patriarchal white sovereignty. Cultural Studies Review 15(2):61-79, doi.org/10.5130/csr.v15i2.2038.

Pick D, Dayaram K \& Butler B (2008). Neoliberalism, risk and regional development in Western Australia: The case of the Pilbara. International Journal of Sociology and Social Policy 28(11/12):516-27, doi.org/10.1108/ 01443330810915224.

Pitty R \& Smith S (2011). The Indigenous challenge to westphalian sovereignty. Australian Journal of Political Science 46(1):121-39, doi.org/10.1080/10361 146.2010.546336.

Sanders W (2014). Experimental governance in Australian Indigenous affairs: From Coombs to Pearson via Rowse and the completing principles. Discussion Paper 291/2014, Centre for Aboriginal Economic Policy Research, The Australian National University, Canberra.

Sullivan P (2011). The policy goal of normalization, the National Indigenous Reform Agreement and Indigenous Partnership Agreements. Desert Knowledge CRC Working Paper Number 76, Australian Institute of Aboriginal and Torres Strait Islander Studies.

Tom N (2005). Debate the De Soto theory. African Business, July(311):23-4.

United Nations (2014). Outcome document of the high-level plenary meeting of the General Assembly known as the World Conference on Indigenous Peoples. United Nations.

United Nations General Assembly (2010). Resolution adopted by the Human Rights Council 15/9 Human rights and access to safe drinking water and sanitation. The Human Rights Council, Fifteenth session, Agenda item 3, 6 October. 
Von Hayek FA (1944). The road to serfdom. Routledge, London.

WA Department of Treasury (2014). The structure of the Western Australian economy. Government of Western Australia.

Yolngu Nations Assembly (2012). Statement from the Second Assembly, Maningrida, 11-13 October. 
This text is taken from The Neoliberal State, Recognition and Indigenous Rights: New paternalism to new imaginings, edited by Deirdre Howard-Wagner, Maria Bargh and Isabel AltamiranoJiménez, published 2018 by ANU Press, The Australian National University, Canberra, Australia.

doi.org/10.22459/CAEPR40.07.2018.03 